\title{
Effect of Good Corporate Governance (GCG) Mechanism on Earning Management Practices and the Impact on Stock Returns (Case Study on LIQUID (1Q 45) Companies Listed in Indonesia Stock Exchange Period 2013-2017)
}

\author{
M. Noor Salim ${ }^{1} \&$ M. Rusman $\mathrm{HN}^{2}$ \\ ${ }^{1}$ Universitas Mercubuana, Indonesia \\ ${ }^{2} \mathrm{PT}$ Waskita Beton Precast Tbk, Indonesia \\ Correspondence: M. Noor Salim, Universitas Mercubuana, Indonesia. Email: m_noorsalim@yahoo.com or \\ 1975801189@mercubuana.ac.id
}

Received: April 25, 2019

doi:10.11114/bms.v5i3.4313
Accepted: June 3, $2019 \quad$ Online Published: June 5, 2019

URL: https://doi.org/10.11114/bms.v5i3.4313

\begin{abstract}
This study aims to analyze the effect of the mechanism of good corporate governance (GCG) on earnings management practices and their impact on stock returns. The population used in this study is the companies included in the go public LQ 45 group listed on the Indonesia Stock Exchange in 2017. The analytical tool used in this study is Eviews software version 8.0. The results of the analysis in this study indicate that (1) Institutional Ownership has a negative and significant effect on Earning Management Practices, (2) Managerial Ownership has a negative and significant effect on Earning Management Practices, (3) Independent Board of Commissioners has a negative and significant effect on Earnings Management, (4) The Audit Committee has a negative and significant effect on Earning Management Practices, (5) Institutional Ownership, Managerial Ownership, Independent Board of Commissioners and Simultaneous Audit Committee (Together) have a significant effect on earnings management, (6) Earning Management Practices have a negative and significant effect on stock returns(7) Institutional Ownership has a positive and significant effect on stock returns, (8) Managerial ownership has a positive and significant effect on stock returns, (9) The Independent Board of Commissioners has a positive and significant effect on stock returns, (10) The Audit Committee has a positive and significant to stock returns, and (11) Earning Management is able to mediate the influence of Institutional Ownership, Managerial Ownership, Independent Board of Commissioners, and the Audit Committee simultaneously (jointly) on Stock Returns. It is recommended that the LQ45 company increase the portion of Institutional ownership as part of a supervision for management in managing the company so as to increase stock returns on an ongoing basis.
\end{abstract}

Contribution/Originality: This study is one of very few studies which have investigated the influence of good corporate governance (GCG) on earnings management practices and their impact on stock returns.

Keywords: agency theory, good corporate governance, earning management, stock return, institutional ownership, managerial ownership, Independent Board of Commissioners, the Audit Committee, LQ 45 company, discretionary accrual

\section{Introduction}

The funds (capital) needed by the company to carry out development are increasingly high, while on the other hand the government's ability to provide funding needs is increasingly limited. To anticipate these conditions, the Indonesian economy requires alternative sources of funds other than through bank loans, namely through the capital market (Gitman, 2012, p. 56)

When the company has been officially registered on the Indonesia Stock Exchange, all matters relating to the company's performance are reported to the public and will receive serious attention from potential investors. For investors, the capital market is an attractive place to invest because it can provide returns that are in accordance with their risk prediction (Hutapea, et al., 2013, p. 242). The company will be very careful in publishing financial statements and other matters relating to company performance because it will be a consideration of investors in making investment decisions 
Given the importance of earnings information as a basis for consideration of someone making an investment decision, the company managers try their best so that the profits contained in the annual report of the publication provide a positive signal to potential investors to invest. Investors will only invest their capital if they are assured that the company is a healthy firm (Salim \& Sudiono, 2017, p. 100)

According to Jogiyanto (2013, p. 51), given the importance of the role of earnings in various decision-making processes, there is a tendency for managers to influence reported earnings of companies with certain motives known as earnings management. The concept of earnings management can be explained using the agency theory approach. The theory states that the practice of earnings management is influenced by conflicts of interest between the parties concerned (principal) and management as those who carry out the interests (agent) (Sedarmayanti, 2012, p. 54).

The rise of earnings management cases can lead to investor distrust of the financial statements presented by the company. Some cases of earnings management occur in Indonesia, especially for companies listed on the Indonesia Stock Exchange (IDX)

Asward and Lina (2015, p. 16) states that the conflict of interest can be minimized through a monitoring mechanism that aims to align the various interests. The corporate governance mechanism can be interpreted as a game rule, procedures, and clear relationships between the parties that make decisions and those, called the monitoring mechanism, who will supervise the decision.

According to Salim (2017, p. 98), the implementation of GCG by the company along with the provisions in it will make the company better than companies that do not implement GCG. According to Sulistyanto (2014, p. 154), the mechanism of Good Corporate Governance (GCG) can be characterized by the presence of Institutional Ownership, Managerial Ownership, the existence of an Independent Board of Commissioners and the Audit Committee.

\section{Theoretical Review}

Agency Theory: Agency theory raises arguments against conflicts between owners, namely shareholders and managers. The conflict arises as a result of differences in interests between the two parties. The existence of company managers has different backgrounds. The first is the party that represents institutional shareholders, while the second is the professionals appointed by the shareholders at the general meeting of shareholders, and those who are aligned with the management of the company because they share ownership. One of the agent's disfunctional behaviors is manipulating data in financial statements to match expectations principal even though the report does not describe the condition of the company which are actually. The manipulation of data in the financial statements can be in the form of earning management practices (Agoes \& Ardana, I Cenik, 2013, p. 91)

Institutional Ownership: Institutional ownership is a condition where the institution has shares in a company (Hamdani, 2016, p. 40). According to Sutedi (2011, p. 82), institutional ownership is share ownership by an external institution. Institutional investors often become the majority in share ownership.

Institutional ownership has a very important role in minimizing agency conflicts that occur between managers and shareholders. The existence of institutional investors is considered capable of being an effective monitoring mechanism in every decision taken by the manager. This is because institutional investors are involved in the strategic retrieval of companies (Agoes \& Ardana, I Cenik, 2013, p. 91).

Institutional ownership can reduce agency cost by activating supervision through institutional investors. This can occur because with institutional involvement in share ownership, company management will be overseen by institutional investors so that management performance will also increase (Hamdani, 2016, p. 50). Institutional ownership is considered the substitution effect of efforts to minimize agency costs through dividend and debt policies. Therefore, to avoid inefficiencies in the use of resources, a lower dividend policy is applied.

Managerial Ownership: According to Sukirni (2012, p. 17), managerial ownership is the shareholders that can also become the owner of the company and the owner of the manager who actively participates in the decision making of the company concerned. According to Sedardamayanti (2012, p. 89), managerial ownership is the level of share ownership of management who actively participates in decision making, measured by the proportion of shares held by managers at the end of the year in\%.

According to Hamdani (2016, p. 75), that to minimize conflict with agency is to increase managerial ownership in the company. The presence of managerial ownership in a company will lead to an interesting suspicion that the company's performance increases as a result of increased management ownership. Ownership by large management will effectively monitor company activities.

Independent Board of Commissioners: According to Fakhruddin (2008, p. 102), the Board of Commissioners are members of the Board of Commissioners who are not affiliated with the Board of Directors, other members of the Board 
of Commissioners and controlling shareholders, who are free from business relationships or other relationships that can affect their ability to act independently or act solely for company interests. Based on the definition above, the author concludes that the independent Board of Commissioners is a member of the commissioner from outside the company (having no affiliation with the company).

Audit Committee: The existence of the Audit Committee is now beginning to be considered in the management of healthy companies. Hamdani (2016, p. 92) argues that Audit Committees are committees formed by the Board of Commissioners of listed companies, whose members are appointed and dismissed by the Board of Commissioners of listed companies to assist the Board of Commissioners of listed companies to conduct necessary checks or research on the management of directors' functions in managing listed company. The duties of the Audit Committee include reviewing the accounting policies applied by the company, assessing internal controls, reviewing the external reporting system that compliance with regulations (Sedarmayanti, 2012, p. 60).

Earning Management: According to Scott (2011, p. 45), earnings management is an intervention of management in the process of preparing financial statements for external parties so that it can flatten, increase, and decrease earnings reporting, where management can use the leeway of using accounting methods, making policies (discreationary) which can accelerate or delay costs and income, so that the company's profits are smaller or larger as expected.

Martani (2012, p. 113) explains that earnings management is an action that regulates the time of recognition of incomes, expenses, profits, or losses in order to achieve certain desired earnings information, without violating the provisions in accounting standards. Usually, earnings management is carried out in the form of increasing profits to achieve certain profit targets and also in the form of decreasing profits in this period, in order to increase income in the future. Rahmayanti (2012, p. 49) explains that earnings management is interfering in the process of preparing external financial reporting, with the aim of obtaining personal benefits (those who disagree say that this is only an effort to facilitate the impartial operation of a process).

Stock Returns: Stock return can be interpreted as a return on stock in accordance with expectations, on an investment that has been made (Jogiyanto, 2013, p. 69). According to Tandelilin (2010, p. 39), the main reason people invest is to make a profit. In the context of investment management, the profit level is referred to as return. In the context of investment management, it is necessary to distinguish between the expected return and the actual return. Hope return is the level of return anticipated by investors in the future, While the actual return is the rate of return that has been obtained by investors in the past (Tandelilin, 2010, p. 40).

\section{Theoretical Framework}

Based on the theory and background above, the following is the framework of the study

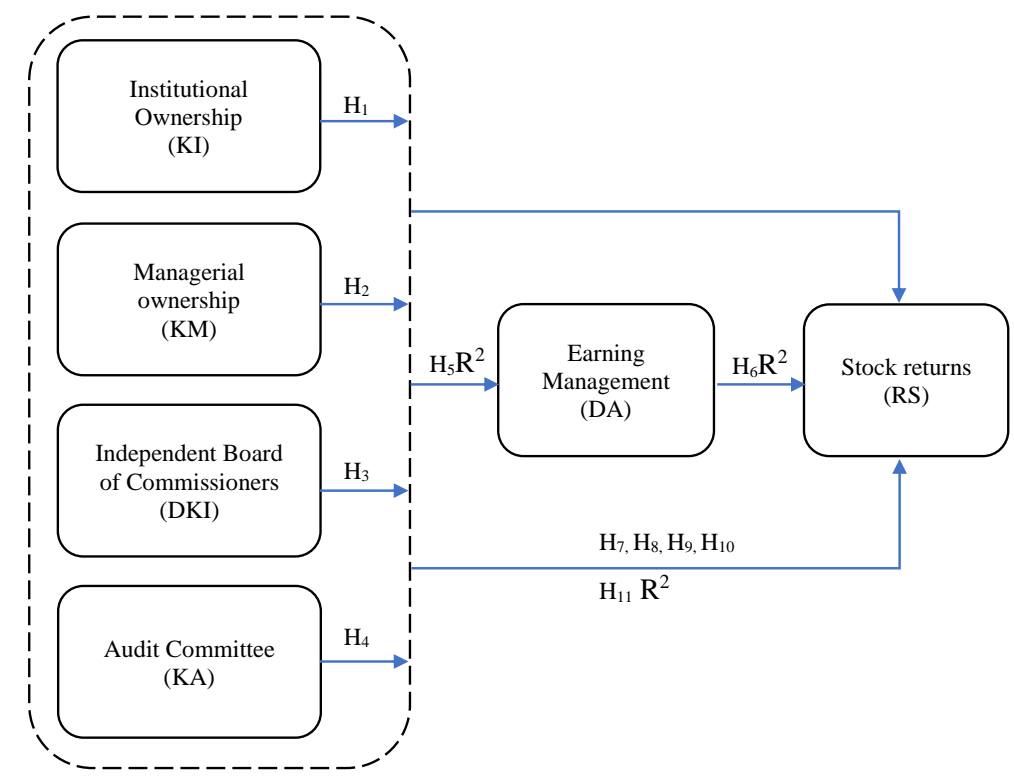

Based on the picture above, it is known that the mechanism of good corporate governance as an independent variable is tested for its effect on earnings management and stock returns. then it will explain the research method used in this study. 
Research Design: The design in this study uses quantitative research methods, in which according to Sugiyono (2013, p. 30) are said to be quantitative methods because research data in the form of numbers and analysis using statistics. This study is a causal explanatory relationship which aims to determine the pattern of causal relationships between research variables. The research design is a guideline that contains the steps that will be followed by the author to conduct his research. The design of the study must be made systematically and logically so that it can be used as a guide that is truly easy to follow.

Population and Sample Research: The population used in this study are companies included in the go public LQ 45 group that are listed on the Indonesia Stock Exchange in 2017. Of the population, there will be a certain number taken as samples.

Data Analysis Method: After selecting a sample, making a model, determining the variables used in the study, and making a hypothesis, the next step is to process the data using regression analysis with panel data. This method is known as the inferential statistical analysis method, which is a statistic used to test hypotheses about a population based on samples as research subjects (Salim, et al., 2018). The regression analysis will be carried out with Eviews software version 8.0. The data panel is data that has the number of cross sections and the number of time series. Data is collected in a time span for many individuals.

\section{Results and Discussion}

This study aims to examine the effect of the mechanism of Good Corporate Governance (GCG) on Earning Management Practices and their Impact on Stock Returns (Case Study on LQ 45 Companies in 2013-2017). Based on the results of sample selection, here are the companies used in this study.

Table 1. The Process of Selecting Research Objects

\begin{tabular}{ll}
\hline No & Criteria \\
1 & LQ 45 Company in 2017 \\
2 & $\begin{array}{l}\text { already listed at the beginning of the study period (2013) and not } \\
\text { delisting until the end of the study period (2017). }\end{array}$ \\
3 & $\begin{array}{l}\text { The company must issue a financial report that lists the value of the } \\
\text { variables to be studied }\end{array}$
\end{tabular}

Number of Companies Number of Companies

Based on table 1, there are 29 companies that are the object of research. The number of units of data analyzed based on the number of companies and the study period (2013-2017) was 145 data units. This study used panel data regression analysis. Through testing panel data regression data analysis, researchers will find out the influence between the variables tested to answer the problem formulation and research hypothesis. The following is the result of panel data regression analysis in the study.

Table 2. Results of Model 1 Data Regression Analysis

\begin{tabular}{|c|c|c|c|}
\hline \multirow{2}{*}{ Chow Test } & Cross-section F & \multicolumn{2}{|c|}{ Conclusion } \\
\hline & 0.000 & \multicolumn{2}{|c|}{ PLS is not the best model } \\
\hline \multirow{2}{*}{ Durbin-Wu-Hausman } & Prob. & \multicolumn{2}{|c|}{ Conclusion } \\
\hline & 0.824 & \multicolumn{2}{|c|}{ Random Effect } \\
\hline \multirow{2}{*}{ Lagrange Multiplier Test } & Prob. Brusch-Godfrey & \multicolumn{2}{|c|}{ Conclusion } \\
\hline & 0.000 & \multicolumn{2}{|c|}{ Random Effect } \\
\hline Variable & Coefficient & t-Statistic & Prob \\
\hline $\mathrm{C}$ & 0.589 & -3.885 & 0.000 \\
\hline KI & -0.289 & -2.690 & 0.005 \\
\hline KM & -0.310 & -2.707 & 0.005 \\
\hline DKI & -0.271 & -2.542 & 0.006 \\
\hline KA & -0.550 & -3.330 & 0.002 \\
\hline \multirow{2}{*}{ F Test } & F-Statistic & Prob & Conclusion \\
\hline & 21.053 & 0.000 & Significant \\
\hline
\end{tabular}


Determination coeffisien ( $R$-Squared) 0.857

Source: Output Eviews 9 (Data Processed)

Based on this, the following is an explanation of the research model:

a. In the Chow Test, it is known that the probability value is 0.000 or $<0.05$ so that it can be concluded that $\mathrm{H} 0$ is rejected and $\mathrm{H} 1$ is accepted, or using a better Fixed Effect Model from Pooled least square Model

b. In the Durbin-Wu-Hausman test, it is known that the probability of a cross section is 0.824 or $>0.05$, then $\mathrm{H} 0$ is accepted and H1 is rejected or using the Random effect Model is better than the Fixed effect Model.

c. In the Lagrange Multiplier Test, it is known that the Breusch - Pagan (BP) probability value is $0.000<0.05$, then $\mathrm{H} 0$ is rejected and $\mathrm{H} 1$ is accepted or uses a random effect approach.

$\mathrm{d}$. The constant value is 0.589 with a significance value of 0.000 . Due to the significance of $<0.05$, then the constant value can be interpreted that if all the independent variables are considered constant or do not change, the magnitude of the Discretionary Accrual (DA) is 0.589.

e. Institutional Ownership regression coefficient (KI) of -0.289 with a significant value of 0.005 . This shows that there is a significant influence. The regression coefficient indicates that Institutional Ownership (KI) increases by one unit, then the Discretionary Accrual (DA) will decrease by 0.289.

f. The regression coefficient value of Managerial Ownership (KM) is -0.310 with a significant value of 0.005 . This shows that there is a significant influence. Regression coefficient figures show if Managerial Ownership (KM) increases by one unit, then Discretionary Accrual (DA) will decrease by 0.310

g. The regression coefficient value of the Independent Board of Commissioners (DKI) is - 0.271 with a significant value of 0.006. This shows that there is a significant influence. The regression coefficient indicates that if the Independent Board of Commissioners (DKI) increases by one unit then the Discretionary Accrual (DA) will decrease by 0.271

h. The Audit Committee (KA) regression coefficient value is -0.550 with a significance value of 0.002 . This shows that there is a significant influence. The regression coefficient shows that if the Audit Quality (KA) increases by one unit then the Discretionary Accrual (DA) will decrease by 0.550 .

i. In the F Test, it is known that the F-Statistic value is 21.053 significant at alpha 0.000 . This shows that simultaneously (jointly) Institutional Ownership (KI), Managerial Ownership (KM), Independent Board of Commissioners (DKI), and Audit Committee (KA) have a significant effect on Discretionary Accrual (DA).

$\mathrm{j}$. The coefficient of determination (R-Squared) is 0.857 . This shows that the percentage contribution of the independent variables to the dependent variable is $85.7 \%$. In other words, it can be interpreted that the independent variables (Institutional Ownership (KI), Managerial Ownership (KM), Independent Board of Commissioners (DKI), and Audit Committee (KA) are able to explain the dependent variable of Earnings Management by $85.7 \%$. While the remaining $14.3 \%$ is influenced by other variables.

Table 3. Data Regression Analysis Model 2

\begin{tabular}{|l|l|l|l|}
\hline \multirow{2}{*}{ Chow Test } & Cross-section F & \multicolumn{2}{l|}{ Conclusion } \\
\cline { 2 - 4 } & 0.867 & \multicolumn{2}{l|}{ PLS is the best model } \\
\hline Variable & Coefficient & t-Statistic & Prob \\
\hline C & 0.804 & 9.257 & 0.000 \\
\hline KI & 0.240 & 2.389 & 0.032 \\
\hline KM & 0.754 & 3.561 & 0.010 \\
\hline DKI & 0.451 & 2.517 & 0.006 \\
\hline KA & 0.280 & 3.595 & 0.002 \\
\hline DA & -0.342 & -2.748 & 0.005 \\
\hline \multirow{2}{*}{ F Test } & F-Statistic & Prob & Conclusion \\
\cline { 2 - 4 } & 20.474 & 0.000 & Significant \\
\hline Determination coeffisien $(R-S q u a r e d)$ & 0.918 & \\
\hline
\end{tabular}

Source: Output Eviews 9 (Data Processed)

Based on this, the following is an explanation of the research model:

a. In the Chow Test, it is known that the probability value is 0.867 or $>0.05$, so it can be concluded that $\mathrm{H} 0$ is accepted and $\mathrm{H} 1$ is rejected, or using Pooled least square Model is the best model. 
b. Constant value of 0.804 with a significant value of 0.000 . Due to the significance of $<0.05$ then the constant value can be interpreted that if all the independent variables are considered constant or having not changed, the amount of Stock Return is equal to 0.804

c. Institutional Ownership regression coefficient (KI) of 0.240 with a significant value of 0.032 . This shows that there is a significant influence. The regression coefficient indicates that Institutional Ownership (KI) increases by one unit so that Stock Returns will increase by 0.240

d. The regression coefficient value of Managerial Ownership (KM) is 0.754 with a significant value of 0.010 . This shows that there is a significant influence. Regression coefficient figures show if Managerial Ownership (KM) increases by one unit, then Stock Returns will increase by 0.754

e. The regression coefficient value of the Independent Board of Commissioners (DKI) is 0.451 with a significant value of 0.006. This shows that there is a significant influence. The regression coefficient indicates that if the Independent Board of Commissioners (DKI) increases by one unit, the Stock Return will increase by 0.451

f. The Audit Committee (KA) regression coefficient value is 0.280 with a significant value of 0.002 . This shows that there is a significant influence. The regression coefficient indicates that if the Audit Committee (KA) increases by one unit, then the Stock Return will increase by 0.280 .

g. Discretionary Accrual (DA) regression coefficient of $-0,342$ with a significant value of 0.005 . This shows that there is a significant influence. The regression coefficient indicates that if the Discretionary Accrual (DA) increases by one unit, the Stock Return will decrease by 0.342

h. In the F Test, it is known that the F-Statistic value is 20.474 significant at alpha 0.000 . This shows that simultaneously (jointly) Institutional Ownership (KI), Managerial Ownership (KM), Independent Board of Commissioners (DKI), Audit Committee (KA), and Accrual Discretionary (DA) have a significant effect on Stock Return.

i. The coefficient of determination (R-Squared) is 0.918. This shows that the percentage contribution of the independent variables to the dependent variable is $91.8 \%$. In other words, it can be interpreted that the independent variables (Institutional Ownership (KI), Managerial Ownership (KM), Independent Board of Commissioners (DKI), Audit Committee (KA), and Discretionary Accrual (DA)) are able to explain variables in which the dependency is $91.8 \%$ while the remaining $8.2 \%$ is influenced by other variables.

Table 4. Intervening Variable Regression Test Results

\begin{tabular}{ll}
\hline Statistics Formulas & $\mathrm{R}$ Square \\
\hline $\mathrm{DA}=0.589-0.289 \mathrm{KI}-0.310 \mathrm{KM}-0.271 \mathrm{DKI}-0.550 \mathrm{KA}+\mathrm{e} \ldots .$. (Eq. 1$)$ & 0.857 \\
$\mathrm{RS}=0.221-0.301 \mathrm{DA}+\mathrm{e} \ldots . .($ Eq. 2$)$ & 0.061 \\
$\mathrm{RS}=0.804+0.240 \mathrm{KI}+0.754 \mathrm{KM}+0.451 \mathrm{DKI}$ & 0.918 \\
$+0.280 \mathrm{KA}-0.342 \mathrm{DA}+\mathrm{e} \ldots . .($ Eq. 3$)$ &
\end{tabular}

Source: Output Eviews 9 (Data Processed)

Based on table 4, it is known that R2 Equation 3> R2 Equation 1 and R2 Equation 3> R2 Equation 2 so that it is concluded that Earning Management Practices is able to mediate the effect of Institutional Ownership, Managerial Ownership, Independent Board of Commissioners, and Audit Committee simultaneously (jointly) on Stock Return.

\section{Discussion of Research Results}

\subsection{Effect of Institutional Ownership on Earning Management Practices}

Based on the results of the study, it is known that Institutional Ownership has a negative and significant effect on Earnings Management. Institutional ownership is part of the company's shares owned by institutional investors, such as insurance companies, financial institutions (banks, financial companies, credit), pension funds, investment banking, and other companies related to these categories (Yang, et al., 2009, p. 32).

Institutional ownership has a negative influence on earnings management practices. The smaller the percentage of institutional ownership, the greater the tendency of managers to take certain accounting policies to manipulate earnings reporting (Agustia, 2013, p. 31). Institutional ownership has the ability to control management through an effective monitoring process so as to reduce earnings management (Hidayanti, et al., 2014, p. 6). The results of this study are in line with previous research conducted by Kazemian and Zuraidah (2015) in which Institutional Ownership has a negative and significant effect on Earnings Management.

\subsection{Effect of Managerial Ownership on Earnings Management}

The results show that Managerial Ownership has a negative and significant effect on Earnings Management. The practice of earnings management is largely determined by the motivation of company managers. Different motivations will produce different amounts of earnings management (Hidayanti, et al., 2014, p. 7). Boediono (2013, p. 65) explains that a 
certain percentage of share ownership by management tends to influence earnings management actions. This is because when managers also have a share of ownership, they will act the same as their general shareholders and ensure that financial statements have been fairly presented and disclose the real conditions of the company (Kouki, et al., 2011, p. 11). Asward and Lina (2015, p. 25) find evidence that managerial ownership has succeeded in becoming a mechanism to reduce agency problems by managers by aligning the interests of managers and shareholders. This study finds that the interests of managers and external shareholders can be put together if the ownership of shares by managers is enlarged so that managers will not manipulate profits for their interests.

\subsection{Effect of the Independent Board of Commissioners on Earning Management Practices}

The results of the study indicate that the Independent Board of Commissioners has a negative and significant effect on Earnings Management. The Independent Board of Commissioners, among others, are in charge and responsible for ensuring that the company has an effective business strategy (monitoring the schedule, budget, and effectiveness of the strategy), complying with applicable laws and regulations, and ensuring that good corporate governance principles and practices are followed and applied well (Sulistyanto, 2014, p. 144). Sochib (2015, p. 36) states that non-executive directors (Independent Board of Commissioners) can act as mediators in disputes that occur between internal managers and oversee management policies and provide advice to management. The results of this study are in line with previous research conducted by Man and Brossa (2013) and found that the Independent Board of Commissioners has a negative and significant effect on Earnings Management.

\subsection{Effect of the Audit Committee on Profit Management}

Based on the results of the study, it is known that the Audit Committee has a negative and significant effect on Earnings Management. The Audit Committee is regulated in Bapepam Circular Letter Number SE3 / PM / 2002 (for public companies) and SOE Minister Decree Number KEP103 / MBU / 2002 (for BUMN). The Audit Committee consists of at least three people, chaired by the company's Independent Commissioner with two independent external people who control and have an accounting and financial background. According to Boediono (2013, p. 71), the Audit Committee is responsible for overseeing financial reports, overseeing external audits, and observing internal control systems (including internal audits) that can reduce the opportunistic nature of management that performs earnings management by monitoring financial statements and conducting supervision of external audits. In line with the opinion of Sulistyanto (2014, p. 156), the Audit Committee is the party responsible for supervising and controlling to create justice, transparency, accountability, and responsibility. These four factors make financial reports more qualified.

\subsection{Effect of Institutional Ownership, Managerial Ownership, Independent Board of Commissioners, and Simultaneous Audit Committee (Together) on Earning Management Practices}

The results show that Institutional Ownership, Managerial Ownership, Independent Board of Commissioners, and Simultaneous Audit Committee (Together) have a significant effect on earnings management. Corporate governance includes the relationship between stakeholders involved and the objectives of management of the company. The main parties in corporate governance are shareholders, management, and the Board of Directors. Other stakeholders include employees, suppliers, customers, banks and other creditors, regulators, the environment, and the community (Agustia, 2013, p. 29). Corporate governance is a concept based on agency theory. The owner will give a number of authorities to managers in running the company's operations. In fact, managers can take a number of actions that tend to seek their own benefit. This is what encourages managers to manage profits at a certain level according to what is required in order to receive bonuses. Through these illustrations, it is clear that a manager can take earnings management actions with the aim of personal interests (Asward \& Lina, 2015, p. 18). The application of good corporate governance is expected to function as a control tool that can help minimize conflicts of interest between owners and managers. Managers no longer attach importance to personal interests, but managers can carry out their responsibilities in accordance with the authority given by the owner. In other words, corporate governance is expected to function to suppress or reduce agency costs and minimize the occurrence of earnings management actions (Hamdani, 2016, p. 77).

\subsection{Effect of Earning Management on Stock Returns}

The results show that Profit Management has a negative and significant effect on Stock Return. The practice of opportunistic earnings management can cause investors to make a wrong investment decision because the information presented does not describe the actual condition and financial position of the company. The high level of opportunistic earnings management in companies indicates the high risk that exists for investors and causes returns to be obtained by investors lower. Based on agency theory predictions that underlie this research, it is assumed that opportunistic earnings management has a negative influence on the company's stock returns.

\subsection{Effect of Institutional Ownership on Stock Returns}


The results show that Institutional Ownership has a positive and significant effect on stock returns. High institutional ownership will lead to greater oversight efforts so that it can hinder the opportunistic behavior of managers. With the concentration of institutional ownership, large shareholders such as institutional investors will be able to monitor the management team more effectively and can increase the value of the company. The internal mechanism can benefit investors, so it will increase returns. The results of this study are in line with previous research conducted by Ferdiansyah and Purnama (2012) that Institutional Ownership has a positive and significant effect on stock returns.

\subsection{Effect of Managerial Ownership on Stock Returns}

The results show that Managerial Ownership has a positive and significant effect on stock returns. Managerial ownership is share ownership by company management as measured by the percentage of shares held by management. Shareholders who have positions in company management both as Directors and as Board of Commissioners are included in managerial ownership. The existence of share ownership by the management will lead to an oversight of the policies taken by the management of the company. With managerial ownership, it will certainly encourage managers to act in line with the wishes of shareholders by increasing performance and responsibility in achieving shareholder prosperity. According to Isnanta (2008, p. 35), management ownership in the company is seen to be able to harmonize potential conflicts of interest between outside shareholders and management. This arises because the company manager who is also a shareholder does not want to make financial statements using earnings management so that the company's earnings management is reduced by managerial ownership. The results of this study are in line with previous research conducted by Murwaningsih (2012), Novian (2012), Rahayu and Faisal (2005) state that managerial ownership has a positive influence on stock returns.

\subsection{Effect of the Independent Board of Commissioners on Stock Returns}

The results of the study indicate that the Independent Board of Commissioners has a positive and significant effect on stock returns. Isnanta (2008, p. 35) states that Independent Board of Commissioners increase effectiveness in overseeing management to prevent fraudulent financial statements. This happened because in Republic of Indonesia, Law No. 40 of 2007 article 108 is regulated regarding the composition of Independent Board of Commissioners, namely at least 1 independent commissioner and 2 commissioners. The existence of this regulation makes the composition of Independent Board of Commissioners between companies equally larg e so that all companies can supervise earnings management practices. The increasing number of Independent Board of Commissioners indicates that the Board of Commissioners performs the function of supervision and coordination in the company the better. The more members of the independent commissioner, the higher the level of integrity of supervision on the Board of Directors.

\subsection{Effect of the Audit Committee on Stock Returns}

The results show that the Audit Committee has a positive and significant effect on stock returns. Jogiyanto (2013, p. 87) argues that the market reacted positively to the announcement of the appointment of Audit Committee members. The main role of the Audit Committee in the company is to help ensure high-quality corporate financial reporting. The Audit Committee and Board of Commissioners are parties that conduct supervision and control to create justice, transparency, accountability, and responsibility which are four factors that make financial reports more qualified (Sulistyanto, 2014, p. 91). Financial reports are important because they are used by investors to get information on the condition of the company's fundamentals which will affect stock prices which will determine the company's stock return. The effectiveness of a high Audit Committee in a company is expected to provide better supervision that can minimize the level of earnings management in the company so that the market tends to react positively (Darwis, 2009, p. 35).

\subsection{Effect of Institutional Ownership, Managerial Ownership, Independent Board of Commissioners, Audit Committee simultaneously (jointly) on Stock Returns with Profit Management as Intervening Variables}

The results show that Earning Management Practices are able to mediate the influence of Institutional Ownership, Managerial Ownership, Independent Board of Commissioners, and Audit Committee simultaneously (jointly) on Stock Return. The practice of earnings management can be prevented by the existence of a good corporate governance system (Bodroastuti, 2009, p. 3). Chi-keung and Brossa (2013, p. 11) state that corporate governance has an effect on monitoring the occurrence of earnings management practices. If the company has implemented good corporate governance properly, then the manager cannot carry out earnings management so that it will have an influence on the stock return of the company.

\section{Conclusion}

Based on the results of research, several conclusions of this study are: 1) Based on the results of the study, it is known that Institutional Ownership has a negative and significant effect on Earnings Management. Institutional ownership has a negative influence on earnings management practices, the smaller the percentage of institutional ownership, the greater the tendency of managers to take certain accounting policies to manipulate earnings reporting, 2) The results of the study show that Managerial Ownership has a negative and significant effect on Earnings Management. Managerial ownership 
has succeeded in becoming a mechanism for reducing agency problems by managers by aligning the interests of managers and shareholders, 3) The results of the study indicate that the Independent Board of Commissioners has a negative and significant effect on Earnings Management. Non-executive directors (Independent Board of Commissioners) can act as mediators in disputes that occur between internal managers and oversee management policies and provide advice to management, 4) Based on the results of the study, it is known that the Audit Committee has a negative and significant effect on Earnings Management. The Audit Committee is responsible for overseeing financial reports, overseeing external audits, and observing internal control systems (including internal audits) that can reduce the opportunistic nature of management that performs earnings management by monitoring financial reports and supervising external audits, 5) The results of the study show that Institutional Ownership, Managerial Ownership, Independent Board of Commissioners, and Simultaneous Audit Committee (Together) have a significant effect on earnings management. The application of good corporate governance is expected to function as a control tool that can help minimize conflicts of interest between owners and managers, 6) The results of the study show that Earning Management Practices has a negative and significant effect on Stock Return. The high level of opportunistic earnings management in companies indicates the high risk that exists for investors, and causes returns to be obtained by investors lower, 7) The results of the study show that Institutional Ownership has a positive and significant effect on stock returns. High institutional ownership will lead to greater oversight efforts so that it can hinder the opportunistic behavior of managers, 8) The results of the study show that Managerial Ownership has a positive and significant effect on stock returns. The existence of share ownership by the management will lead to an oversight of the policies taken by the management of the company, 9) The results of the study indicate that the Independent Board of Commissioners has a positive and significant effect on stock returns. The more members of the Independent Commissioner, the higher the level of integrity of supervision on the board of directors. The high integrity of supervision will increasingly represent the interests of other stakeholders other than the interests of the majority shareholders, and the impact will be better for the value of the company, 10) The results of the study indicate that the Audit Committee has a positive and significant effect on stock returns. The effectiveness of a high Audit Committee in a company is expected to provide better supervision that is able to minimize the level of earnings management in the company so that the market tends to react positively, 11) The results of the study indicate that Earning Management Practices are able to mediate the influence of Institutional Ownership, Managerial Ownership, Independent Board of Commissioners, and the Audit Committee simultaneously (jointly) on Stock Returns. The results show that Earning Management Practices are able to mediate the influence of Institutional Ownership, Managerial Ownership, Independent Board of Commissioners, and Audit Committee simultaneously (jointly) on Stock Return.

\section{References}

Agoes, \& Ardana, I. C. (2013). Profession and Business Ethics. In The Challenge of Building a Whole Man. Jakarta: Salemba Empat.

Agustia, D. (2013). Effect of Factors of Good Corporate Governance, Free Cash Flow, and Leverage on Earning Management. Journal of Accounting and Finance. 15(1). https://doi.org/10.9744/jak.15.1.27-42

Asward, I., \& Lina. (2015). Effect of Corporate Governance Mechanism on Earning Management with the Conditional Revenue Model Approach. Journal of Technology Management. Vol. 14 No. 1.

https://doi.org/10.12695/jmt.2015.14.1.2

Bodroastuti, T. (2009). Effect of Corporate Governance Structure on Financial Distress. Journal of Business and Accounting. 9(1).

Boediono. (2013). Series of Synopsis for Introduction to Economics, No.1. Microeconomics. Second edition. Twenty-eighth print. Yogyakarta: BPFE.

Darwis, H. (2009). Corporate Governance of Company Performance. Journal of Finance and Banking, 13(3).

Fakhruddin, H. M. (2008). Capital Market Term from A to Z . Jakarta: Elex Media Komputindo.

Ferdiansyah, \& Purnama, D. (2012). Effect of Earning Management on Stock Returns with Investor Intelligence as Moderating Variables. Journal of Science \& Management Accounting. 4(2).

Gitman, L. J. (2012). Principles of Managerial Finance. 13th Edition. Pearson Education Limited.

Hamdani, G. (2016). Good Corporate Governance Review of Ethics in Business Practices. Jakarta: Mitra Wacana Media.

Hidayanti, E., Ratna, W., \& Dahniar, P. (2014). Effect of Good Corporate Governance on the Practice of Earning Management in Manufacturing Companies. Jurnal WIGA, 4(2).

Hutapea, E. C., Tyara, P., \& Pardomuan, S. (2013). Analysis of Valuation of Fair Value of PT. Adaro Energy Tbk Uses Free-Cash Flow to Firm. Journal of Applied Finance and Accounting, 5(2). 
Isnanta, R. (2008). Effect of Corporate Governance and Ownership Structure on Earnings Management and Financial Performance. In Thesis. Faculty of Economics, Islamic University of Indonesia.

Jogiyanto, H. (2013). Portfolio Theory and Investment Analysis. Yogyakarta: BPFE.

Kazemian, S., \& Zuraidah, M. S. (2015). Earnings Management and Ownership Structure. Procedia Economics and Finance, 31. https://doi.org/10.1016/S2212-5671(15)01149-1

Kouki, M., Abderrazek, E., Hanen, A., \& Slim, S. (2011). Does Corporate Governance Constrain Earnings Management? Evidence from U.S. Firms. European Journal of Economics, Finance and Administrative Sciences, 35.

Man, C. K., \& Brossa, W. (2013). Corporate Governance And Earnings Management: A Survey Of Literature. The Journal of Applied Business Research, 29(2). https://doi.org/10.19030/jabr.v29i2.7646

Martani, D. (2012). Intermediate Financial Accounting Based on PSAK. 2nd Book. Jakarta: Salemba Empat.

Murwaningsih. (2012). Effect of Ownership Structure on Stock Returns. Journal of Media Research Accounting, Auditing and Information, 12(1).

Novian, F. (2012). Importance of Red Flag For Independent Auditors to Detect Fraud in Financial Statements. Journal of Accounting, 1(3).

Rahayu, D. S., \& Faisal. (2005). Effect of Managerial and Institutional Ownership on the Capital Structure of the Company. Journal of Business and Accounting, 7(2).

Rahmayanti, E. (2012). Analysis of the Effect of the Mechanism of Corporate Governance on Earning Management and Company Performance (Empirical Study of Manufacturing Companies Listed on the Indonesia Stock Exchange). Journal of the Faculty of Economics. University of Indonesia.

Salim, M. N., \& Sudiono. (2017). An Analysis of Bankruptcy Likelihood on Coal Mining Listed Firms in The Indonesian Stock Exchange: An Altman, Springate and Zmijewski Approaches. Eurasian Journal of Economics and Finance, 5(3). https://doi.org/10.15604/ejef.2017.05.03.008

Salim, M. N., Abdul, B. D., Fitriya, F. Y., \& Mohammad, I. Y. (2018). Multivariate Statistics: Analysis of Anova, Manova, Ancova, Mancova, Repeated Measured with Excel and SPSS Applications. Depok: PT Raja Grafindo Persada.

Salim, M. N., Sugeng, S., Tri, W., \& Irma, S. (2017). Intellectual Capital and Corporate Governance in Financial Performance Indonesia Islamic Banking. International Journal of Economics and Financial Issues, 7(4).

Scott, W. R. (2011). Financial Accounting Theory. Sixth Edition. Canada: Person Prentice Hall.

Sedarmayanti. (2012). Human Resource Management. Jakarta: Refika Aditama Eresco.

Sochib. (2015). Effect of the Implementation of Good Corporate Governance on Profit Management and Financial Performance. WIGA Journal, 5(1).

Sugiyono. (2013). Educational Research Methods Quantitative, Qualitative and R \& D Approaches. Bandung: Alfabeta.

Sukirni, D. (2012). Managerial Ownership, Institutional Ownership, Dividend Policy and Debt Policy Analysis of Company Values. Journal of Accounting Analysis, 1(2).

Sulistyanto, H. S. (2014). Earning Management, Theory and Empirical Models. Jakarta: Grasindo.

Sutedi, A. (2011). Good Corporate Governance. Jakarta: Sinar Grafika.

Tandelilin, E. (2010). Portfolio and Investment Theory and Application. First edition. Yogyakarta: Kanisius IKAPI.

Yang, W. S., Loo, S. C., \& Shamser. (2009). The Effect of Board Structure and Institutional Ownership Structure on Earnings Management. International Journal of Economics and Management, 3(2). 
Copyright for this article is retained by the author(s), with first publication rights granted to the journal.

This is an open-access article distributed under the terms and conditions of the Creative Commons Attribution license which permits unrestricted use, distribution, and reproduction in any medium, provided the original work is properly cited. 